INTERNATIONAL JOURNAL OF RESEARCHES IN BIOSCIENCES, AGRICULTURE AND TECHNOLOGY (C) VISHWASHANTI MULTIPURPOSE SOCIETY (Global Peace Multipurpose Society) R. No. MH-659/13(N) www.vmsindia.org

\title{
DIVALENT CADMIUM RECOVERY BY LIQUID- LIQUID EXTRACTION WITH 2-OCTYLAMINOPYRIDINE FROM ACIDIC BROMIDE MEDIA AND IT'S SEPARATION FROM OTHER TOXIC METAL IONS
}

\author{
C. P. Mane ${ }^{1}$, M. K. Sakate ${ }^{1}$ D. V. Rupnawar ${ }^{1}$, R. A. Nalawade ${ }^{1,2}$, \\ A. M. Nalawade ${ }^{1}$, R.V. Shejwal ${ }^{1}$ and M. A. Anuse ${ }^{2}$ \\ ${ }^{1}$ Lal bahadur Shastri college Satara, India. \\ ${ }^{2}$ Shivaji university, Kolhapur, India. \\ E-mail: shekharpmane@yahoo.co.in
}

\begin{abstract}
:
A systematic study of extraction of Cadmium (II) with 2-octylaminopyridine (2-OAP) in xylene at room temperature has been conducted. Quantitative extraction of Cadmium (II) was observed in the 0.7 to $1.0 \mathrm{M}$ concentration range of hydrobromic acid. From the extracted complex species in the organic phase, Cadmium (II) was back extracted with water $(3 \times 15 \mathrm{~mL})$ and was determined by EDTA titration. Various parameters such as 2-OAP concentration, equilibrium period, effect of various diluents, aqueous: organic volume ratio, acidity and diverse ions were studied. The extraction reaction proceeds with ion- pair formation and the stoichiometry of extracted species was found to be $\left[\left(2-\mathrm{OAPH}^{+}\right)_{2} \text {. }\left(\mathrm{CdBr}_{4}\right)\right]^{-2}$ (org). The separation and determination of cadmium (II) from associated toxic metal ions in binary and ternary mixtures containing $\mathrm{Zn}$ (II), $\mathrm{Tl}$ (I), $\mathrm{Pb}$ (II), $\mathrm{Sb}$ (II) $\mathrm{Cr}$ (VI) \& $\mathrm{Hg}$ (II) were carried out by taking advantage of masking agent.
\end{abstract}

Keywords- liquid- liquid extraction Cd(II),Bromide media,2-OAP, xylene

\section{Introduction:}

Cadmium, its alloys and compounds are used in a variety of consumer and industrial materials. About $70 \%$ of cadmium is consumed as active electrode materials $\mathrm{Ni}-\mathrm{Cd}$ batteries and the rest in pigments $(12 \%)$ and stabilizers for PVC and light (15\%). The only cadmium mineral of importance, is nearly always associated with sphalerite. Consequently, cadmium is primarily produced as a byproduct from mining, smelting and refining of sulphide ore concentrates of zinc and to a lesser degree, $\mathrm{Pb}$ and $\mathrm{Cu}$. Secondary cadmium is recovered from spent nickelcadmium batteries. The united state geological survey (USGS) estimated world resources of cadmium at about 6 million tonnes based on $\mathrm{Zn}$ resources containing about $0.3 \%$ cadmium. Hydrometallurgical methods of treating cadmium containing minerals generates leach liquors having impurities such as $\mathrm{Co}, \mathrm{Ni}, \mathrm{Fe}$ along with cadmium.

Heavy toxic metals, cadmium is concentrated in soil may pose health hazards to plants and animals [1]. This metal has been found to have deterious effects on both human being and plant metabolism. The excessive uptake of cadmium from the soil creates a dual problem. Harvested crops, so contaminated serves as a source of heavy metals in our food supply. Which has potentially harmful effects on human health. It is well known that cadmium concentration in plant tissues is usually directed to the concentration of plant availabled cadmium in soil [2]. A little information is available on cadmium uptake by strawberry species or distribution of cadmium within the plant including accumulation in time fruit.

The method for purification and recovery of cadmium from solution can be achieved by precipitation, ion exchange, solvent extraction etc. Among the various purification methods, solvent extraction technique appears to be commercially competitive and many plants are being operated for the production of pure metals [3].

\section{Experimental:}

An Elico-digital pH meter model LI-120 was used for $\mathrm{pH}$ measurement. An Elico-digital spectrophotometer model SL-172 with $1 \mathrm{~cm}$ quartz cells was used for absorbance measurements. Tapson's analytical single pan balance model $200 \mathrm{~T}$ having $0.001 \mathrm{gm}$ accuracy was used for weighing operations.

\section{Reagents}

Cadmium (II) solution

3.135 gms of A.R. grade $\mathrm{CdSO}_{4} .8 \mathrm{H}_{2} \mathrm{O}$ (Merck) was weighed on analytical one pan balance. $2.5 \mathrm{~mL}$ concentrated sulphuric acid was added in the salt and dissolved in double distilled water. The solution was diluted for $1000 \mathrm{~mL}$. A $1 \mathrm{mg} / \mathrm{mL}$ cadmium(II) solution was produced which was standardized by complexometric titration $[4,5]$.

\section{EDTA Solution (0.01 M)}

3.722 gms of disodium salt of EDTA $(\mathrm{BDH})$ was dissolved in double distilled water and diluted to $1000 \mathrm{~mL}$. A $0.01 \mathrm{M}$ EDTA solution was produced. It was standardized by complexometric titration [ 4,5].

Thorium nitrate solution (0.01 M) 
$0.01 \mathrm{M}$ solution was prepared by dissolving 5.880 gms of thorium nitrate tetra hydrate $(\mathrm{BDH})$ in water and diluting to $1000 \mathrm{~mL}$.

\section{2- Octylaminopyridine solution (2-OAP)}

It was synthesized by Borshch and Petrukhin method [6] $0.0848 \quad M \quad(1.75 \%) \quad 2-$ octylaminopyridine solution was prepared in xylene (S.d.fine).

Working solutions were prepared by accurate dilutions and standardization. Double distilled water was used for preparation of solutions and their dilutions. Analytical grade chemicals BDH, Merck, Loba and s.d. fine were used.

\section{General extraction and determination procedure}

Distribution experiments were done at $298 \pm 0.1$ $\mathrm{K}$. The volumes of the aqueous phase containing $0.5 \mathrm{mg}$ of cadmium(II) and 1 mole / $\mathrm{dm}^{3}$ hydrobromic acid and the organic phase containing $0.0845 \mathrm{M} 2$-OAP in xylene in the proportion of 2.5:1 were placed in a $125 \mathrm{~mL}$ separatory funnel and was equilibrated for 2 min, which was sufficient for reaching the extraction equilibrium. Both the phases were separated by waiting for $30 \mathrm{~min}$. The aqueous phase was washed with $5 \mathrm{~mL}$ xylene and rejected. The cadmium(II) from the organic phase was back stripped with distilled water (3x15 mL). The aqueous phase was evaporated to moist dryness, with $10 \mathrm{~mL}$ hydrochloric acid.The residue was dissolved in distilled water and evaporated to most dryness and dissolved in distilled water, diluted for $25 \mathrm{~mL}$ and the cadmium(II) from the solution was determined by complexometric titration $[4,5]$.
The extraction was found to be quantitative from hydrobromic acid at its 0.7 to $1 \mathrm{M}$ concentration with $0.0848 \mathrm{M}(1.75 \%)$ 2-OAP in xylene.The aqueous and organic phases were equilibrated for 2 minuts. For overall extraction procedure distilled water $(3 \times 15 \mathrm{~mL})$ was used as a back extractant . Various diluents such as benzene, xylene, toluene, MIBK, kerosene, nbutanol, amyl acetate, chloroform, carbon tetrachloride and 1,2-dichloroethane were used for the extraction of cadmium(II) while 2-OAP in xylene and in benzene gave quantitative extraction for cadmium(II). The effect of various foreign ions on the extraction of cadmium(II) with $10 \mathrm{~mL} 0.0845 \mathrm{M} \mathrm{2-OAP}$ in xylene at $1 \mathrm{M}$ hydrobromic acid media was studied. The tolerance limit of the foreign ion was taken as the amount required to cause an error of not more than $\pm 2 \%$ in the cadmium(II) recovery. It was observed that the method is free from interference of several foreign ions in the procedure. However, $\mathrm{NO}_{2}{ }^{-}$and $\mathrm{Pb}(\mathrm{II})$ ions interfered in the extraction procedture. The interference of $\mathrm{Pb}$ (II) was eliminated by masking with $50 \mathrm{mg}$ of thiosulphate The results are reported in Table 1

The nature of the extracted species was investigated by the conventional slope analysis

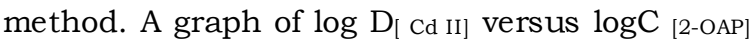
at 0.2 and $0.4 \mathrm{M}$ hydrobromic acid concentration gave slope of 2.1 and 2.2 , respectively indicating the metal to amine ratio in the extracted specis is $1: 2$ and the probable extracted species is

$\left[\left(2-\mathrm{OAP}^{+}\right)_{2} \cdot \mathrm{CdBr}_{4}^{-2}\right]$ (org). The probable extraction mechanis $\mathrm{m}$ is given as,

\title{
Results and Discussion:
}

\author{
$2-\mathrm{OAP}{ }_{(\mathrm{org})}+\mathrm{H}^{+}{ }_{(\mathrm{aq})} \rightleftharpoons \quad\left[2-\mathrm{OAPH}^{+}\right]$(org) $\quad \ldots . . . \mathrm{I}$ \\ $\mathrm{Cd}^{2+}+4 \mathrm{Br}{ }^{-} \rightleftharpoons\left[\mathrm{CdBr}_{4}\right]^{2-} \quad \ldots \ldots . . \mathrm{II}$ \\ $2\left[2-\mathrm{OAPH}^{+}\right]$(org) $+\left[\mathrm{Cd} \mathrm{Br}_{4}\right]^{2-}{ }_{\text {(aq) }} \rightleftharpoons\left[\left(2-\mathrm{OAPH}^{+}\right)_{2 .}\left(\mathrm{CdBr}_{4}^{-2}\right)\right]_{\text {(org) }} \quad \ldots . \mathrm{III}$
}

\begin{abstract}
Applications
Separation and determination of cadmium(II) from binary mixtures containing toxic metals

The suitability of the above developed method was examined by applying it to the separation and determination of cadmium(II) and other toxic metals from there binary mixtures [Table 2]. It was found that $\mathrm{Tl}(\mathrm{I}), \mathrm{Zn}(\mathrm{II}), \mathrm{Sb}(\mathrm{III}), \mathrm{Cr}(\mathrm{VI})$ and $\mathrm{Hg}(\mathrm{II})$, remained unextracted in aqueous phase under the optimum extraction conditions of cadmium(II) using $1 \mathrm{M}$ hydrobromic acid with $10 \mathrm{~mL} 0.0845 \mathrm{M} \mathrm{2-OAP}$ in xylene. . The metal
\end{abstract}

cations remained in aqueous phase were determined by standard methods [4,5,7,8 ].The extracted organic phase was stripped with water $(3 \times 15 \mathrm{~mL})$ and the cadmium(II) from the aqueous phase was estimated by recommended procedure.

Cadmium(II) was separated from $\mathrm{Pb}(\mathrm{II})$ by masking the $\mathrm{Pb}(\mathrm{II})$ with $50 \mathrm{mg}$ of thiosulphate. Cadmium(II) was quantitatively extracted into organic phase while $\mathrm{Pb}(\mathrm{II})$ was remained in aqueous phase. Lead(II) was determined from the aqueous phase by standard 
method [4,5] while, cadmium(II) from the organic phase was back extracted with three 15 $\mathrm{mL}$ portions of distilled water and estimated by the recommended procedure.

Separation and determination of cadmium(II) in the synthetic mixture containing toxic metals

A solution containing $0.500 \mathrm{mg}$ of cadmium(II) was taken and known amount of other metals were added. Extraction of cadmium (II) was carried out by use of developed extraction procedure. The results obtained were in good agreement with an amount added [Table 3]. The selectivity of extraction of cadmium(II) can also be achieved by use of a suitable masking agent for added metal ion.

Table: 1 : Effect of foreign ions

\begin{tabular}{|l|l|}
\hline $\begin{array}{l}\text { Ratio of ion } \\
\text { Cd(II) :added metal ion }\end{array}$ & Anion / Cation \\
\hline $1: 200$ & Flouride, iodide, thiocyanate, thiourea, sulphate, salicylate, malonate \\
\hline $1: 100$ & Bromide, thiosulphate, phosphate, citrate, ascorbate, oxalate \\
\hline $1: 50$ & Nitrate, tartrate \\
\hline $1: 40$ & Ni(II), $\mathrm{Hg}(\mathrm{II}), \mathrm{Tl}(\mathrm{I}), \mathrm{Se}(\mathrm{IV}), \mathrm{Ca}(\mathrm{II}), \mathrm{Sr}(\mathrm{II})$ \\
\hline $1: 30$ & $\mathrm{Sb}(\mathrm{III}), \mathrm{Bi}(\mathrm{III}), \mathrm{Te}(\mathrm{IV}), \mathrm{Mg}(\mathrm{II}), \mathrm{Ba}(\mathrm{II}), \mathrm{Mo}(\mathrm{VI})$ \\
\hline $1: 20$ & $\mathrm{EDTA}, \mathrm{Mn}(\mathrm{II}), \mathrm{Mn}(\mathrm{VII}), \mathrm{Sn}(\mathrm{IV}), \mathrm{Ga}(\mathrm{III})$ \\
\hline $1: 10$ & Acetate, $\mathrm{Cr}(\mathrm{III}), \mathrm{Zn}(\mathrm{II}), \mathrm{Sn}(\mathrm{II})$ \\
\hline $1: 6$ & $\mathrm{~V}(\mathrm{~V}), \mathrm{Cr}(\mathrm{VI}), \mathrm{Fe}(\mathrm{II}), \mathrm{Fe}(\mathrm{III}), \mathrm{Co}(\mathrm{II})$ \\
\hline $1: 2$ & $\mathrm{Cu}(\mathrm{II}), \mathrm{Pb}(\mathrm{II}) \mathrm{a}, \mathrm{In}(\mathrm{III})$ \\
\hline
\end{tabular}

$\mathrm{a}-$ masked by $50 \mathrm{mg} \mathrm{S}_{2} \mathrm{O}_{3^{-}}$

Table : 2 : Separation of cadmium (II) from binary mixtures

\begin{tabular}{|l|l|l|}
\hline Metal ion & Amount added,(mg) & Average Recovery,* \%R \\
\hline $\mathrm{Cd}(\mathrm{II})$ & 0.5 & 99.30 \\
\hline $\mathrm{Zn}(\mathrm{II})$ & 0.5 & 99.19 \\
\hline $\mathrm{Cd}(\mathrm{II})$ & 0.5 & 100 \\
\hline $\mathrm{Tl}(\mathrm{I})$ & 1.0 & 99.30 \\
\hline $\mathrm{Cd}(\mathrm{II})$ & 0.5 & 99.67 \\
\hline $\mathrm{Pb}(\mathrm{II}) \mathrm{a}$ & 1.0 & 99.09 \\
\hline $\mathrm{Cd}(\mathrm{II})$ & 0.5 & 100 \\
\hline $\mathrm{Sb}(\mathrm{III})$ & 0.5 & 98.83 \\
\hline $\mathrm{Cd}(\mathrm{II})$ & 0.5 & 99.07 \\
\hline $\mathrm{Cr}(\mathrm{VI})$ & 1.0 & 97.22 \\
\hline $\mathrm{Cd}(\mathrm{II})$ & 0.5 & 98.84 \\
\hline $\mathrm{Hg}(\mathrm{II})$ & 1.0 & 99.99 \\
\hline
\end{tabular}

* - Average of six determinations a - masked by $50 \mathrm{mg} \mathrm{S}_{2} \mathrm{O}_{3^{--}}$

Table: 3: Separation and determination of cadmium(II) from synthetic mixtures containing toxic metals

\begin{tabular}{|ll|l|l|l|}
\hline $\begin{array}{l}\text { Composition } \\
\text { (mg) }\end{array}$ & $\begin{array}{l}\text { Cadmium(II) } \\
\text { Found mg }\end{array}$ & $\begin{array}{l}\text { Recovery* } \\
\text { \% }\end{array}$ & RSD \\
\hline $\mathrm{Cd}(\mathrm{II})$ & 0.5 & & 99.07 & 0.93 \\
$\mathrm{~Pb}(\mathrm{II}) \mathrm{a}$ & 1.0 & 0.495 & & \\
$\mathrm{Cr}(\mathrm{VI})$ & 1.0 & & 99.30 & 0.7 \\
\hline $\mathrm{Cd}(\mathrm{II})$ & 0.5 & & & \\
$\mathrm{Zn}(\mathrm{II})$ & 0.5 & 0.497 & 99.54 & 0.46 \\
$\mathrm{Hg}(\mathrm{II})$ & 1.0 & & & \\
\hline $\mathrm{Cd}(\mathrm{II})$ & 0.5 & & & \\
$\mathrm{Zn}(\mathrm{II})$ & 0.5 & 0.498 & 99.07 & 0.93 \\
$\mathrm{~Pb}(\mathrm{II}) \mathrm{a}$ & 1.0 & & & \\
\hline $\mathrm{Cd}(\mathrm{II})$ & 0.5 & & & \\
$\mathrm{Sb}(\mathrm{III})$ & 0.5 & 0.495 & 99.30 & 0.7 \\
$\mathrm{Tl}(\mathrm{I})$ & 1.0 & & & \\
\hline $\mathrm{Cd}(\mathrm{II})$ & 0.5 & & & \\
$\mathrm{Hg}(\mathrm{II})$ & 0.5 & 0.497 & & \\
$\mathrm{~Pb}(\mathrm{II}) \mathrm{a}$ & 1.0 & &
\end{tabular}




\begin{tabular}{|ll|l|l|l|}
\hline $\mathrm{Cd}(\mathrm{II})$ & 0.5 & & & \\
$\mathrm{Sb}(\mathrm{III})$ & 0.5 & 0.499 & 99.99 & 0.01 \\
$\mathrm{Hg}(\mathrm{II})$ & 1.0 & & & \\
\hline
\end{tabular}

* - Average of six determinations a - masked by $50 \mathrm{mg} \mathrm{S}_{2} \mathrm{O}_{3^{--}}$

\section{References:}

[1.] D. W. Allinson, C. Dzialo, The influence of lead, cadmium, and nickel on the growth of ryegrass and oats., Plant and Soil, 62 (1981) 81-89.

[2.] G. Cieslinski, G. H. Neilsen, E. J. Hogue, Effect of soil cadmium application and $\mathrm{pH}$ on growth and cadmium accumulation in roots, leaves and fruits of strawberry plants., (Fragariax ananassa Duch) Plant and Soil, 180 (1996) 267-276.

[3.] B. R. Reddy, D. N. Priya, J. R. Kumar, Solvent extraction of cadmium from sulphate solution using sodium salts of Tops-99, PC- 88 A, cyanex-272 and their mixtures., Proceedings of ISSE Bhubaneswar India, (2002) 123-134.
[4.] A. I. Vogel, A textbook of quantitative inorganic analysis, forth ed ${ }^{\mathrm{n}}$., ELBS, London, 1961

[5.] F. J. Welcher, The Analytical uses of Ethylenediamine tetraacetic acid, D. Van. Nostrand Compan, Inc.New York, 1958.

[6.] N. A. Borshch, O. M. Petrukhin, 2octylaminopyridine a new extractant, $\mathrm{Zh}$. Anal. Khim., 99(1978) 1385-1391

[7.] Z. Marckzenko, Spectroscopic determinations of elements, Ellis Horwood Limited, Chinchester, 1976.

[8.] E. B. Sandell, Colorimetric determinations of traces metals, third ed ${ }^{\mathrm{n}}$, interscience, New York, 1965. 